\title{
A Study on Influence of Economic Preparation for Later Life after Retirement
}

\author{
Jong-Jin KIM ${ }^{1}$ \\ Received: December 20, 2019 Revised: March 15, 2020 Accepted: March 31, 2020
}

\begin{abstract}
This study examines how economic preparation for later life directly influences life after retirement. As people's life cycle is gradually getting longer, preparation for the later time with less economic activity after retirement is becoming more important. Thus, this study analyzes the factors influencing life after retirement. Data comes from the Korean Retirement and Income Study (KReIS) surveyed carried out by the National Pension Research Institute in 2015. The analysis includes Cronbach's alpha, Pearson Product Moment Correlation Coefficient and Sobel Test. This study confirms that voluntary retirement has a positive influence on life satisfaction. Results are in line with previous research about the relationship between voluntary retirement and retired life. When a person retires voluntarily, financial preparation can be made in advance for retirement. In case of involuntary retirement, people may experience a sense of loss in personal standing and financial difficulties due to the unexpected situation. Especially, early retirement from the main workplace leads to unstable later life. The study's policy recommendation, in particular, calls on government and businesses to agree on social responsibility for helping employees to retire in the predictable retirement time and, thus, enabling the retiree to decide all aspects of the path after retirement.
\end{abstract}

Keywords : Economic Preparation for Later Life, Voluntariness in Retirement, Life Satisfaction after Retirement, Saving Propensity Index, Liquidity Index, Investment Propensity Index.

JEL Classification Code : I31, J14, E24, H23

\section{Introduction}

In South Korea, the aging of the population is proceeding in unprecedentedly fast speed compared to any other countries. Although this involves a positive side such as the longevity of the older population, rapid aging without detailed preparation or personal preparation may cause various social pathological problems (Lee \& Lee, 2015).

While advanced countries have been preparing aging for a long time, South Korea lacks preparation on later life in the aging society. As a result, the rapid increase in old population may cause increased numbers of elderly and bigger social issues (Kim \& Choi, 2017).

With longer later life, elderly are going through problems such as health issue, economic issue, loss of standing,

${ }^{1}$ First Author and Corresponding Author. Manager, Social Economic UNHABITAT, Korea. E-mail: 2001j2k@hanmail.net

(c) Copyright: The Author(s)

This is an Open Access article distributed under the terms of the Creative Commons Attribution Non-Commercial License (http://Creativecommons.org/licenses/by-nc/4.0/) which permits unrestricted noncommercial use, distribution, and reproduction in any medium, provided the original work is properly cited. loneliness, feeling of isolation, and support issue. Elderly are perceived as a serious social problem causing a burden on the society or the home, and these are problems caused by aging. In response, there is growing interest on figuring out the fundamental cause influencing the preparation for later life (Lee \& Lee, 2015).

Preparation for later life is one of the important requirements for maintaining a quality of life. When a person is not prepared for the later life, the person goes through difficulty in adapting to later life and feeling of loss. This results in rapid economic deterioration. Thus, one would go through fewer difficulties in later life after preparing for how to spend life in old age (Roach, 1981).

The sustenance allowance for elderly in Korea increased from $7.4 \%$ in the 1990 s and $16.1 \%$ in 2012 , showing rapid increase in social burden for supporting the old population. This is likely to cause disputes between the old population and the productive age group leading to negative influence on social integration (Mazzonna \& Peracchi, 2012).

In this respect, self-reliance in later life on the personal level is getting more important. To live a successful later life after retirement, one needs to prepare for the later life 
personally. While there is increasing emphasis on personal responsibility in later life preparation, the actual level of later life preparation is extremely low. More than half of the households are not prepared for their later life prior to retirement, and these households show low level in the objective index and financial preparation index. With regard to household savings, a representative index for later life preparation, South Korea shows household savings of $3.2 \%$ lower than the average household savings $(8.5 \%)$ of 17 OECD member countries, and the figure is even falling gradually. These households are showing smaller savings and lacking fund for later life preparation because they lack awareness on how later life preparation directly influences retirement or later life. Although later life preparation is a long-term task to be settled throughout the life cycle, people start to think about preparing for later life after their retirement. As a result, people try to cut down expenditure just before retirement and they cannot prepare for the later life well due to the inability to do so (Kim \& Choi, 2017).

Nevertheless, there is no previous research on factors influencing the retried life. Also, this study seeks to identify what would be appropriate factors for influencing the satisfaction in the retired life. Since there has not been much related research, this study is more significant.

Thus, this study explores how economic preparation for later life directly influences the life after retirement. As people's life-cycle is gradually getting longer, preparation for a later time with less economic activity after retirement is getting more important. In response, this study plans to analyze the factors influencing the life after retirement.

\section{Theoretical Background}

\subsection{Necessity of Later Life Preparation}

When people retire without any economic plans for later life, they encounter various social or personal problems such as a decline in economic level, lower standing at home, and lack of opportunity for social activity. As the advanced countries went through elderly issue in the early stage, both the elderly and the government prepare for the later life. In case of South Korea, however, the elderly issue is in a transitional period, and most people spend their whole income on family living, child rearing, education, and medical expenses. Then, they end up not getting prepared for their own later life and there are only few policies related to later life preparation (Rohwedder \& Willis, 2010).

After retirement, one needs to spend a retired life without guarantee on economic income for 20 to 25 years. Individuals need to prepare for the later life in varies aspects such as income security, health care, and leisure life.

Especially, the unemployed old population is rising rapidly in Korea due to the increase in average life expectancy, rapid industrialization, and early retirement for age-limit system. As a result, senior welfare and senior employment are becoming social issues. If people fail to prepare for loss of income due to early retirement, they cannot avoid facing poverty in later life. Thus, it is necessary to make longterm plans and find ways for economic and psychological independence (Spreitzer, 1995).

\subsection{Economic Preparation for Later Life}

Economic preparation for later life refers to saving funds for guaranteeing economic independence in the later life. When people lack economic preparation and fail to arrange basic support in the later life, this leads to economic difficulty in old age and may have negative influence on overall living (Choi \& Lee, 2007).

Identifying the economic preparation for later life is identifying the financial status of the family. This can be examined with consumption expenditure structure, savings, and fund.

Household savings is an index for measuring the progress in accomplishing the long-term financial goal of the household. This index is used as the representative index for measuring the preparation for later life (Coe, Gaudecker, Lindeboom, \& Maurer, 2012).

According to the life-cycle model, savings are the mean for making the present and future consumption hold the highest utility within the limited resource. Household saves money during the work period before retirement to maintain the level of living during the retired life. Then, this brings the increased saving, fund, and wealth in the household. Such savings, fund, and wealth can be used as emergency fund or as fund for accomplishing the future goal (Cho \& Kim, 2005).

Since the economic situation may influence one's later life and the economic life of the family, one should plan for the later life thoroughly by utilizing national pension, retirement pension, personal pension, and various other deposit, installment savings, investment product, and real estate by calculating the living fund necessary for later life based on own expenditure and inflation (Cho \& Kim, 2005).

\subsection{Relationship between Economic Preparation for Later Life and Life Satisfaction After Retirement}

Preparation for later life is the process and plan to arrange the resources necessary for later life and getting prepared for a happy and successful later life.

In regard to the relationship between specific later life preparation and life satisfaction, previous studies focused on the economic preparation for the later life and reported a positive relationship between economic preparation for the 
later life and life satisfaction (Berry, Kim, Minde, \& Mok, 1988).

Those studies analyzed how economic preparation for later life controls the influence on retiree's subjective health consciousness and life satisfaction (Berkowitz \& Benbenishty, 2012).

Studies also showed that national pension does not influence life satisfaction, and pointed out the insufficient guarantee and relativity of economic return of pension system.

According to research, one should predict and prepare in advance as various issues such as health, income, loneliness, retirement problem, life preparation, time usage, financial problem, and relationship with married children, happen during the retirement period (Berry, Kim, Minde, $\&$ Mok, 1988). Thus, preparing for such changes before and after retirement would have a positive influence on life satisfaction.

Based on these studies, this article focuses on economic preparation for later life in the perspective of assets and finance instead of pension or security insurance (Berkowitz \& Benbenishty, 2012).

\subsection{Voluntariness in Retirement}

The reason for retirement is the characteristic variable related to retirement. It influences the quality of life after retirement as the preparation for retired life changes whether the person retires voluntarily or involuntarily (Denier, Clouston, Richards, \& Hofer, 2017).

The elderly's decision on retirement is related to a personal perception toward retirement. The idea started from the interest on whether the elderly leaving the labor market voluntarily or elderly forced to leave the labor market would have higher life satisfaction. Although it has been reported that voluntary retirees over 65 show higher satisfaction compared to people forced to retire, this study identified that the personal decision made by elderly between 55 64 had a non-deterministic impact on life satisfaction. In most of the previous studies related to decision-making in retirement, the retirees showed higher life satisfaction when they had more control on time and conditions of retirement (Kim \& Choi, 2017),

According to the survey on the economically active population as of May 2012 reported by Statistics Korea, the average age of retirement after the longest service was 53 and $43.2 \%$ of people retired at the age of 50 . In the statistics, $27.0 \%$ retired because of 'business turndown, cessation of operation, temporary closing, and shutdown' while $7.9 \%$ of elderly retired for 'official suggestion to resign, early voluntary retirement, and layoff'. By adding the people retiring from regular retirement $(10.7 \%)$ as a compulsory regulation, about $1 / 3$ of elderly among the total number of retirees retire regardless of own will. This demonstrates that Korean labor market policy does not guarantee the voluntariness in retirement. According to 2013 OECD statistics, the actual retirement age in Korea is 71.4 (as of 2011) and this shows that it takes about 18 years for a person to leave the labor market completely after retiring from the main workplace. As retirement starts from people in their 50s, and the entry into retirement is closely related to employment instability, the labor and welfare policy mark the clear boundary between economic activity and noneconomic activity or employment and unemployment may lead to the exclusion of various laborers in the vulnerable social group (Denier, Clouston, Richards, \& Hofer, 2017).

According to international research on involuntary leave and retirement, most of the elderly workers in the 1970s and 1980s had no options for retirement and the companies notified them of the retirement age. Some of the workers also had to leave work at an earlier age due to health issues. In addition, a research published in 1980 pointed out that retirement age, health, and workplace issues might be the reasons for involuntary retirement. Previous studies also pointed out how involuntary retirement has a negative influence before and after the retirement. These international research about involuntary retirement analyzed the factors influencing the involuntary retirement based on the perception toward involuntary retirement or suggested the influence of perception toward involuntary retirement on life satisfaction after retirement (Kontis, Bennett, Mathers, Foreman, \& Ezzati, 2017).

In response, this study seeks to examine the influence on the voluntariness in retirement based on these previous studies.

\section{Methodology}

\subsection{Subject of Investigation}

This study used Korean Retirement and Income Study (KReIS) surveyed by National Pension Research Institute in 2015. KReIS is a survey of national households and household members conducted every other year since 2015 and it is based on questionnaires to household, to collect personal information on individual as well as on their occupational history.

The $6^{\text {th }}$ KReIS survey included 5, 254 members of households with a householder over 50. To examine the relationship between later life preparation and retirement life, this study utilized personal data based on serial number for household member.

As this study found it appropriate to examine the household in terms of degree of later life preparation before the old age for the research subject, this study analyzed by targeting the middle-aged people who haven't reached the 
old age. Based on the view that retirement period starts from 50 , this study selected subjects over 50 and conducted an analysis on 3,312 subjects who retired from the work.

\subsection{Research Model}

The purpose of this study is to verify the moderating effect of voluntariness in retirement to examine the factors of later life preparation influencing on the retired life. This study analyzed control variables as socio-demographic characteristics. The research model for this study is as Figure.1.

\subsection{Research Hypothesis}

The research hypotheses are based on variables selected from previous studies as follows:

H1a: Economic preparation for later life will have a positive influence on the retired life.

H1b: Economic preparation for later life will have a positive influence on psychological changes after retirement.

H1c: Economic preparation for later life will have a positive influence on life satisfaction after retirement.

H2a: Voluntariness in retirement will have a moderating effect on later life preparation's positive influence on retirement life.

H2b: Voluntariness in retirement will have a moderating effect on later life preparation's positive influence on psychological changes after retirement.

H2c: Voluntariness in retirement will have a moderating effect on later life preparation's positive influence on life satisfaction after retirement.

\subsection{Measuring Tool}

\subsubsection{Independent Variable}

Household members who economically prepare for the later life would have characteristics different from others who do not prepare. Supporting people by identifying such characteristics would enhance overall economic later life

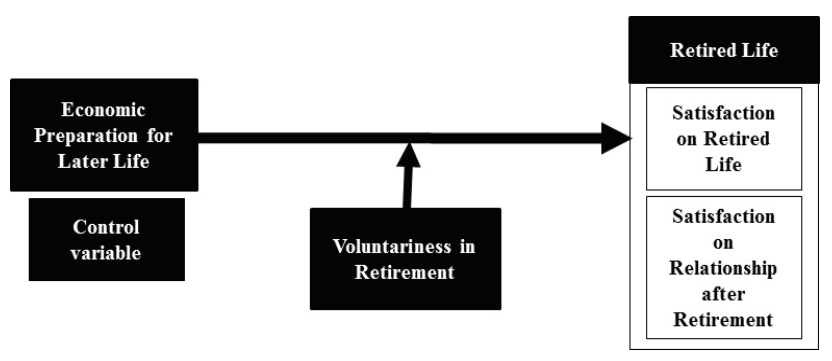

Figure 1: Research model preparation. Thus, this study sets the degree of later life preparation as the independent variable to find out factors influencing on the objective degree of economic preparation for the later life.

To measure the degree of economic preparation for later life objectively, this study examined the financial index factors. Based on the retirement asset for later life preparation suggested in previous research, this study sets 'Saving Propensity Index (Total rate of saving in a household)', 'Liquidity Index (Proportion of financial assets)', and 'Investment Propensity Index (Proportion of real-estate property assets)' among the growth indexes related to Korean model for later life preparation as the variables for measuring the degree of later life preparation most accurately. Each variable was included in the analysis by converting into natural logarithms (Lee \& Lee, 2015).

\section{Saving Propensity Index}

The first index for the degree of later life preparation is 'Saving Propensity Index'. This index refers to the total ratio of saving in the household calculated by the proportion of total annual saving to total annual income of the household.

According to life-cycle income hypothesis, saving is the resource for later life formed by adjusting the consumption during the period of high income in preparation for the old age. In response, numerous preceding researches used variables regarding saving to measure the degree of later life preparation.

Saving propensity index is used as an indicator for evaluating the long-term growth of household assets. As a result, the ratio of saving in the middle-aged household will help in predicting the amount of assets for later life in the future. This study sets a formula on a static criterion for the total ratio of saving in the household for the later life by referring to the criteria suggested by the other research.

Saving Propensity Index $=\{$ (Total annual saving of the household / Total annual income of the household) $\left.)^{*} 100\right\}$

\section{Liquidity Index}

The second index for the degree of later life preparation is 'Liquidity Index'. This index is measured by the proportion of financial asset in the total assets. Also, total assets have been calculated by summing up real-estate property, financial assets, and other assets.

Financial assets are the future-oriented assets necessary for long-term growth and soundness of the household. Liquidation of assets is easier when the ratio of financial assets is higher. As the financial assets have a high liquidity, this assets play important role as the reserve assets for emergency such as later life with low income. 
In this study, liquidity index (proportion of financial assets) holds figure ranging from 0 to $100(\%)$ and higher percentage refers to higher proportion of financial assets.

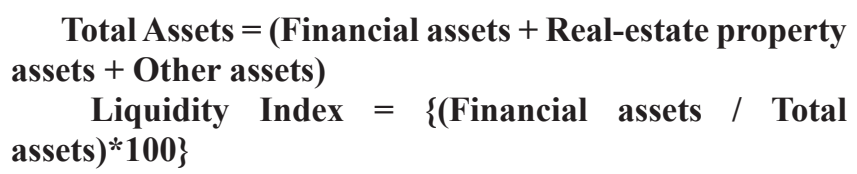

Total Assets $=($ Financial assets + Real-estate property assets + Other assets)

Liquidity Index $=\{$ (Financial assets $/$ Total assets)*100\}

\section{Investment Propensity Index}

The third index for the degree of later life preparation is 'Investment Propensity Index' and this study examined the proportion of real-estate property assets in total assets.

In case of Korea, the accumulation of wealth is largely made in the form of real-estate property assets. Thus, it is important to examine the proportion of real-property assets in identifying the assets of the household. Since the real-estate property assets take up the largest proportion in the assets income of the household, they are evaluated as the important economic source for retired/old household. While real-estate property assets provide high profitability in the long term, the real-estate property assets need to be in appropriate proportion to the financial assets because excessively high proportion of real-estate property in total assets lowers liquidity and increases risks relatively.

Considering the previous studies' controversy on whether to include the resident house in the real-estate property assets, this study composed the index by using the real-estate property assets including resident house and related assets. The index figure ranges from 0 to $100(\%)$ and proportion of investment assets is higher when the figure is higher.

Investment Propensity Index $=\{($ Real-estate property assets including house / Total assets)*100\}

\subsubsection{Dependent Variable- Satisfaction of Retired Life}

To measure the contents about retirement, the Korean Retirement and Income Study (KReIS) used on this study has been divided into psychological part and satisfaction part. Then, this study measured the psychological part by dividing the positive and negative aspects on psychological changes and conditions after retirement.

Secondly, this study divided the satisfaction component into various life aspects and personal relationship to measure the life satisfaction of the subjects. Based on the ideas on life satisfaction from previous research, this study analyzed the important factors regarding retired life by dividing into living satisfaction and relationship satisfaction.

In the measurement of psychological changes in retired subjects from KReIS, this study divided the psychological changes into negative and positive condition change. Among the 20 psychological analysis items, this study classified and organized positive and negative psychological changes.
To measure the life satisfaction of the subject, the items are divided into parts about various aspects of life and personal relationship. The items are composed of 12 questions as follows. (1) Housing (2) Relationship with neighbor, (3) Economic status, (4) Occupation, (5) Relationship with friend, (6) Relationship with family, (7) Married life, (8) Health, (9) Overall life,(10) Relationship with child, (11) Relationship with brother and sister, (12) Leisure life.

\subsubsection{Moderator Variable - Voluntariness in Retirement}

This study measured the retiree's voluntariness in retirement with a single item by dividing the conditions of retirement into (1) Quitted job with own will (2) Quitted job involuntarily regardless of intention to work. To identify the voluntariness in retirement, this study classified whether the retirement was voluntary or forced.

\subsection{Data Analysis}

For the statistical data analysis, this study used SPSS 21.0 program. As this study covers the respective discussion on influential relationship between variables such as economic preparation for later life, voluntariness in retirement, and retired life while having discussion on the general perspective, deriving the result in this analysis method holds strengthen in having a logical persuasive power.

First, this study conducted an exploratory factor analysis to enhance the internal validity of the tool measuring the economic preparation later life, voluntariness in retirement, and retired life.

Second, this study analyzed the internal consistency by calculating the Cronbach's alpha between variables classified through the exploratory factor analysis.

Third, this study conducted Pearson Product Moment Correlation Coefficient to analyze the correlation between economic preparation for later life, voluntariness in retirement, and retired life based on socio-demographic characteristics.

Fourth, this study conducted a hierarchical analysis to analyze the influence between variables of economic preparation for later life, voluntariness in retirement, and retired life based on socio-demographic characteristics.

Fifth, this study carried out a Sobel Test to examine the influence on the parameter. This model is the volume statistics used in the social studies field to compose the relationship between variables in a concise and proper way. This model is mainly used on verification of hypothesis for analyzing the theory toward a certain phenomenon. It combines factor analysis and regression analysis for analysis of cause and effect and it refers to the equation model used for identifying the causal relationship between models through measurement model and structural model. 


\section{Research Results}

\subsection{Analysis on Influence of Economic Preparation for Later Life and Retired Life}

Table 1 shows the hierarchical regression model between variables influencing on the positive psychological change among the psychological changes after retirement.

In Model 1, the variance for positive psychological change and economic preparation for the later life is $11.1 \%$. Among the sub-variables of economic preparation for later life, saving propensity index $(\mathrm{t}=4.383, \mathrm{p}=.000)$ and liquidity index $(\mathrm{t}=1.724, \mathrm{p}=.035)$ showed influence.

Model 2 is the result after additional regression analysis on Model 1's moderator variable, voluntariness in retirement. Model 2 explains the variance of $22.3 \%$. In Model 2, saving propensity index $(\mathrm{t}=4.263, \mathrm{p}=.000)$ and liquidity index $(\mathrm{t}=$ 1.734, $\mathrm{p}=0.023$ ) had a positive influence on the positive psychological change.

Table 2 shows the hierarchical regression model between variables influencing on the negative psychological change among the psychological changes after retirement.

In Model 1 about the retired life's sub-variables on psychological changes after retirement, the variance for negative psychological change and later life preparation was
$10.3 \%$. The saving propensity index $(\mathrm{t}=-2.281, \mathrm{p}=.023)$ and liquidity index $(=-1.209, \mathrm{p}=.027)$ of economic preparation for later life influenced on negative psychological changes.

Model 2 is the result after additional regression analysis on Model 1's moderator variable, voluntariness in retirement. Model 2 explains the variance of 23.9\%. In Model 2, saving propensity index $(\mathrm{t}=-2.329, \mathrm{p}=.020)$ and liquidity index $(=-1.233, \mathrm{p}=0.018)$ influenced on negative psychological changes.

Table 3 shows the hierarchical regression model between variables influencing on the degree of satisfaction over retired life among retirement satisfactions. In Model 1 and retired life's sub-variable, retirement satisfaction, variance for the degree of satisfaction over retired life and later life preparation was $13.5 \%$. The saving propensity index $(\mathrm{t}=8.687, \mathrm{p}=.000)$ and liquidity index $(\mathrm{t}=2.437$, $\mathrm{p}=.015$ ) for economic preparation for later life had a significant positive influence on the degree of retired life satisfaction. Model 2 is the result after additional regression analysis on Model 1's moderator variable, voluntariness in retirement. Model 2 explains the variance of $27.2 \%$. Also, the saving propensity index $(\mathrm{t}=2.551, \mathrm{p}=.011)$, liquidity index $(\mathrm{t}=2.551, \mathrm{p}=.011)$, and voluntariness in retirement $(\mathrm{t}=8.425, \mathrm{p}=.000)$ had a positive influence on the degree of retired life satisfaction.

Table 1: Hierarchical Regression Analysis on Positive Psychological Change Among Psychological Changes after Retirement

\begin{tabular}{|c|c|c|c|c|c|c|c|c|c|c|}
\hline & \multirow{2}{*}{$\begin{array}{l}\text { Variable } \\
\text { B }\end{array}$} & \multicolumn{2}{|c|}{$\begin{array}{c}\text { Non } \\
\text { standardization } \\
\text { factor }\end{array}$} & \multirow[t]{2}{*}{$\begin{array}{c}\text { Standardization } \\
\text { factor }\end{array}$} & \multirow[t]{2}{*}{$\mathbf{t}$} & \multirow{2}{*}{$\begin{array}{c}\text { P. } \\
\text { value } \\
\text { allowance }\end{array}$} & \multicolumn{2}{|c|}{$\begin{array}{l}\text { communist } \\
\text { statistics }\end{array}$} & \multirow[t]{2}{*}{$\mathbf{R}^{2}$} & \multirow[t]{2}{*}{$\mathbf{F}$} \\
\hline & & $\begin{array}{c}\text { standard } \\
\text { error }\end{array}$ & Beta & & & & VIF & & & \\
\hline \multirow{4}{*}{ Model1 } & (Constant) & 2.002 & .055 & & 36.469 & .000 & & & \multirow{4}{*}{.111} & \multirow{4}{*}{8.811} \\
\hline & \begin{tabular}{|l|} 
Saving \\
Propensity Index
\end{tabular} & .179 & .041 & .087 & 4.383 & .000 & .929 & 1.076 & & \\
\hline & \begin{tabular}{|l} 
Liquidity Index \\
\end{tabular} & .001 & .000 & .035 & 1.724 & .035 & .872 & 1.147 & & \\
\hline & \begin{tabular}{|l|} 
Investment \\
Propensity Index
\end{tabular} & .027 & .024 & .023 & 1.129 & .259 & .904 & 1.106 & & \\
\hline \multirow{5}{*}{ Model 2} & \begin{tabular}{|l} 
(Constant) \\
\end{tabular} & .352 & .324 & & 1.086 & .278 & & & \multirow{5}{*}{.223} & \multirow{5}{*}{7.999} \\
\hline & $\begin{array}{l}\text { Saving } \\
\text { Propensity Index }\end{array}$ & .174 & .041 & .084 & 4.263 & .000 & .925 & 1.081 & & \\
\hline & Liquidity Index & .001 & .000 & .035 & 1.734 & .023 & .872 & 1.147 & & \\
\hline & $\begin{array}{l}\text { Investment } \\
\text { Propensity Index }\end{array}$ & .030 & .024 & .025 & 1.229 & .219 & .895 & 1.117 & & \\
\hline & $\begin{array}{l}\text { Voluntariness in } \\
\text { Retirement }\end{array}$ & .016 & .023 & .013 & .676 & .499 & .982 & 1.018 & & \\
\hline
\end{tabular}

a. Dependent Variable: Positive psychological change 
Table 2: Hierarchical Regression Analysis on Negative Psychological Change Among Psychological Changes after Retirement

\begin{tabular}{|c|c|c|c|c|c|c|c|c|c|c|}
\hline & \multirow{2}{*}{$\begin{array}{l}\text { Variable } \\
\text { B }\end{array}$} & \multicolumn{2}{|c|}{$\begin{array}{c}\text { Non } \\
\text { standardization } \\
\text { factor }\end{array}$} & \multirow[t]{2}{*}{$\begin{array}{l}\text { Standardization } \\
\text { factor }\end{array}$} & \multirow[t]{2}{*}{$\mathbf{t}$} & \multirow{2}{*}{$\begin{array}{c}\text { P. } \\
\text { value } \\
\text { allowance }\end{array}$} & \multicolumn{2}{|c|}{$\begin{array}{l}\text { communist } \\
\text { statistics }\end{array}$} & \multirow[t]{2}{*}{$\mathbf{R}^{\mathbf{2}}$} & \multirow[t]{2}{*}{$\mathbf{F}$} \\
\hline & & $\begin{array}{c}\text { standard } \\
\text { error }\end{array}$ & Beta & & & & VIF & & & \\
\hline \multirow{4}{*}{$\begin{array}{c}\text { Model } \\
1\end{array}$} & (Constant) & .547 & .043 & & 12.611 & .000 & & & \multirow{4}{*}{.103} & \multirow{4}{*}{2.362} \\
\hline & $\begin{array}{l}\text { Saving } \\
\text { Propensity Index }\end{array}$ & -.074 & .032 & -.045 & -2.281 & .023 & .929 & 1.076 & & \\
\hline & Liquidity Index & .000 & .000 & -.025 & -1.209 & .027 & .872 & 1.147 & & \\
\hline & $\begin{array}{l}\text { Investment } \\
\text { Propensity Index }\end{array}$ & -.006 & .019 & -.006 & -.291 & .771 & .904 & 1.106 & & \\
\hline \multirow{5}{*}{$\begin{array}{l}\text { Model } \\
2\end{array}$} & (Constant) & 2.270 & .253 & & 8.985 & .000 & & & \multirow{5}{*}{.239} & \multirow{5}{*}{15.224} \\
\hline & $\begin{array}{l}\text { Saving } \\
\text { Propensity Index }\end{array}$ & -.074 & .032 & -.046 & -2.329 & .020 & .925 & 1.081 & & \\
\hline & Liquidity Index & .000 & .000 & -.025 & -1.233 & .018 & .872 & 1.147 & & \\
\hline & $\begin{array}{l}\text { Investment } \\
\text { Propensity Index }\end{array}$ & -.010 & .019 & -.010 & -.523 & .601 & .895 & 1.117 & & \\
\hline & $\begin{array}{l}\text { Voluntariness in } \\
\text { Retirement }\end{array}$ & .002 & .018 & .002 & .118 & .906 & .982 & 1.018 & & \\
\hline
\end{tabular}

a. Dependent Variable: Negative psychological change

Table 3: Hierarchical Regression Analysis on Degree of Retired Life Satisfaction Among Retirement Life

\begin{tabular}{|c|c|c|c|c|c|c|c|c|c|c|}
\hline & \multirow{2}{*}{$\begin{array}{c}\text { Variable } \\
\text { B }\end{array}$} & \multicolumn{2}{|c|}{$\begin{array}{c}\text { Non } \\
\text { standardization } \\
\text { factor }\end{array}$} & \multirow[t]{2}{*}{$\begin{array}{c}\text { Standardization } \\
\text { factor }\end{array}$} & \multirow[t]{2}{*}{$\mathbf{t}$} & \multirow{2}{*}{$\begin{array}{c}\text { P- } \\
\text { value } \\
\text { allowance }\end{array}$} & \multicolumn{2}{|c|}{$\begin{array}{l}\text { communist } \\
\text { statistics }\end{array}$} & \multirow[t]{2}{*}{$\mathbf{R}^{2}$} & \multirow[t]{2}{*}{$\mathbf{F}$} \\
\hline & & $\begin{array}{l}\text { standard } \\
\text { error }\end{array}$ & Beta & & & & VIF & & & \\
\hline \multirow{4}{*}{$\begin{array}{l}\text { Model } \\
1\end{array}$} & (Constant) & 2.793 & .054 & & 52.186 & .000 & & & \multirow{4}{*}{.135} & \multirow{4}{*}{32.828} \\
\hline & $\begin{array}{l}\text { Saving } \\
\text { Propensity Index }\end{array}$ & .346 & .040 & .170 & 8.687 & .000 & .929 & 1.076 & & \\
\hline & Liquidity Index & .001 & .000 & .049 & 2.437 & .015 & .872 & 1.147 & & \\
\hline & $\begin{array}{l}\text { Investment } \\
\text { Propensity Index }\end{array}$ & -.033 & .024 & -.027 & -1.373 & .170 & .904 & 1.106 & & \\
\hline \multirow{5}{*}{$\begin{array}{l}\text { Model } \\
2\end{array}$} & (Constant) & .911 & .311 & & 2.926 & .003 & & & \multirow{5}{*}{.272} & \multirow{5}{*}{29.707} \\
\hline & $\begin{array}{l}\text { Saving } \\
\text { Propensity Index }\end{array}$ & .320 & .039 & .157 & 8.181 & .000 & .925 & 1.081 & & \\
\hline & Liquidity Index & .001 & .000 & .051 & 2.551 & .011 & .872 & 1.147 & & \\
\hline & $\begin{array}{l}\text { Investment } \\
\text { Propensity Index }\end{array}$ & -.015 & .023 & -.013 & -.651 & .515 & .895 & 1.117 & & \\
\hline & $\begin{array}{l}\text { Voluntariness in } \\
\text { Retirement }\end{array}$ & .189 & .022 & .157 & 8.425 & .000 & .982 & 1.018 & & \\
\hline
\end{tabular}

a. Dependent Variable: Degree of Retired Life Satisfaction 
Table 4 shows the hierarchical regression model between variables influencing on the degree of satisfaction over relationship after retirement among retirement satisfaction.

In Model 1 and retired life's sub-variable, retirement satisfaction, it explains variance for retirement relationship satisfaction and later life preparation by $13.1 \%$. Economic preparation for later life's saving propensity index $(t=5.973$, $\mathrm{p}=.000)$ and investment propensity index $(\mathrm{t}=-6.784, \mathrm{p}=$ .000) were significant in overall relationship satisfaction after retirement. Also, while saving propensity index had a positive influence on the relationship satisfaction after retirement, investment propensity index had a negative influence on the relationship satisfaction after retirement.

Model 2 is the result after additional regression analysis on Model 1's moderator variable, voluntariness in retirement/ Model 2 explains the variance of $27.2 \%$. Also, the saving propensity index $(\mathrm{t}=5.419, \mathrm{p}=.000)$, liquidity index $(\mathrm{t}=-6.784$, $\mathrm{p}=.011)$, and voluntariness in retirement $(\mathrm{t}=9.111, \mathrm{p}=.000)$ influenced on the relationship satisfaction after retirement.

\subsection{Measurement of Moderator Variable for Voluntariness in Retirement}

It's necessary to identify whether the $\mathrm{R}^{2}$ increased by getting revised for the moderating effect in following
Table 5. To examine the influence of interactive term in the third stage, the increase in $\mathrm{R}^{2}$ matters.

$\mathrm{R}^{2}$ showed gradual increase in Model 1 to $3.3 \%$, Model 2 to $7.0 \%$, and Model 3 to $7.3 \%$ and the variation in F-value was less than 0.01 .

Such result showed that saving propensity index among economic preparation for later life's sub-variable has moderating effect of voluntariness in retirement in the causal relationship of retired life satisfaction.

When VIF is over 10 in multi-collinearity, it is regarded that collinearity has issues. Since VIF was under 10 in this study, there is no influence of collinearity issue between variables.

As shown in Table 6, $\mathrm{R}^{2}$ showed gradual increase in Model 1 to $1.0 \%$, Model 2 to $4.8 \%$, and Model 3 to $4.9 \%$ and the variation in F-value was less than 0.05 . This explains that liquidity index among the sub-variable of economic preparation for later life has a moderating effect in the voluntariness in retirement for the influencing relationship of retired life satisfaction among the retirement satisfaction.

As shown in Table 7, $\mathrm{R}^{2}$ showed gradual increase in Model 1 to $2.8 \%$, Model 2 to $4.0 \%$, and Model 3 to $4.2 \%$ and the variation in $\mathrm{F}$-value was less than 0.05 . This explains that investment propensity index among the sub-variable of economic preparation for later life and has a moderating

Table 4: Hierarchical Regression Analysis on Relationship Satisfaction after Retirement

\begin{tabular}{|c|c|c|c|c|c|c|c|c|c|c|}
\hline & \multirow{2}{*}{$\begin{array}{c}\text { Variable } \\
\text { B }\end{array}$} & \multicolumn{2}{|c|}{$\begin{array}{c}\text { Non } \\
\text { standardization } \\
\text { factor }\end{array}$} & \multirow[t]{2}{*}{$\begin{array}{l}\text { Standardization } \\
\text { factor }\end{array}$} & \multirow[t]{2}{*}{$t$} & \multirow{2}{*}{$\begin{array}{c}\text { P- } \\
\text { value } \\
\text { allowance }\end{array}$} & \multicolumn{2}{|c|}{$\begin{array}{l}\text { communist } \\
\text { statistics }\end{array}$} & \multirow[t]{2}{*}{$\mathbf{R}^{2}$} & \multirow[t]{2}{*}{$F$} \\
\hline & & $\begin{array}{c}\text { standard } \\
\text { error }\end{array}$ & Beta & & & & VIF & & & \\
\hline \multirow{4}{*}{$\begin{array}{c}\text { Model } \\
1\end{array}$} & (Constant) & 3.330 & .061 & & 54.531 & .000 & & & \multirow{4}{*}{.131} & \multirow{4}{*}{28.385} \\
\hline & $\begin{array}{l}\text { Saving } \\
\text { Propensity } \\
\text { Index }\end{array}$ & 271 & .045 & 1117 & 5.973 & .000 & .929 & 1.076 & & \\
\hline & Liquidity Index & .000 & .000 & .014 & .693 & .488 & .872 & 1.147 & & \\
\hline & $\begin{array}{l}\text { Investment } \\
\text { Propensity } \\
\text { Index }\end{array}$ & -.184 & .027 & -.135 & -6.784 & .000 & .904 & 1.106 & & \\
\hline \multirow{5}{*}{$\begin{array}{l}\text { Model } \\
2\end{array}$} & (Constant) & 1.195 & .355 & & 3.367 & .001 & & & \multirow{5}{*}{.170} & \multirow{5}{*}{29.149} \\
\hline & $\begin{array}{l}\text { Saving } \\
\text { Propensity } \\
\text { Index }\end{array}$ & .242 & .045 & .104 & 5.419 & .000 & .925 & 1.081 & & \\
\hline & Liquidity Index & .000 & .000 & .016 & .790 & .430 & .872 & 1.147 & & \\
\hline & $\begin{array}{l}\text { Investment } \\
\text { Propensity } \\
\text { Index }\end{array}$ & -.163 & .027 & -.120 & -6.100 & .000 & .895 & 1.117 & & \\
\hline & $\begin{array}{l}\text { Voluntariness } \\
\text { in Retirement }\end{array}$ & .233 & .026 & .170 & 9.111 & .000 & .982 & 1.018 & & \\
\hline
\end{tabular}

a. Dependent Variable: Relationship Satisfaction after Retirement 
Table 5: Verification on Moderator Variable toward Saving Propensity Index and Retired Life Satisfaction

\begin{tabular}{|c|c|c|c|c|c|c|c|c|c|c|c|}
\hline \multirow[b]{2}{*}{ Model } & \multirow[b]{2}{*}{$\mathbf{R}$} & \multirow[b]{2}{*}{$\mathbf{R}^{2}$} & \multirow[b]{2}{*}{$\begin{array}{l}\text { Modified } \\
\qquad \mathbf{R}^{2}\end{array}$} & \multirow{2}{*}{$\begin{array}{l}\text { Standard } \\
\text { error of } \\
\text { estimated } \\
\text { value }\end{array}$} & \multicolumn{5}{|c|}{ Statistics Variation } & \multicolumn{2}{|c|}{$\begin{array}{l}\text { communist } \\
\text { statistics }\end{array}$} \\
\hline & & & & & $\begin{array}{c}\mathbf{R}^{2} \\
\text { change } \\
\text { amount }\end{array}$ & $\begin{array}{c}\text { F } \\
\text { change } \\
\text { amount }\end{array}$ & df1 & df2 & $\begin{array}{l}\text { significant } \\
\text { probability } \\
\text { F variation }\end{array}$ & allowance & VIF \\
\hline 1 & $.181 a$ & .033 & .033 & .625 & .033 & 111.677 & 1 & 3290 & .000 & 1.000 & 1.000 \\
\hline 2 & $.264 b$ & .070 & .069 & .613 & .037 & 130.229 & 1 & 3289 & .000 & .997 & 1.003 \\
\hline 3 & $.270 c$ & .073 & .072 & .613 & .003 & 11.175 & 1 & 3288 & .001 & .735 & 1.361 \\
\hline
\end{tabular}

a. Predictive value: (Constant), Saving Propensity Index

b. Predictive value: (Constant), Saving Propensity Index, Voluntariness in Retirement

c. Predictive value: (Constant), Saving Propensity Index, Voluntariness in Retirement, Saving Propensity Index *

Voluntariness in Retirement

d. Dependent variable : Life Satisfaction after Retirement

Table 6: Verification on Moderator Variable toward Liquidity Index and Retired Life Satisfaction

\begin{tabular}{|c|c|c|c|c|c|c|c|c|c|c|c|}
\hline \multirow[b]{2}{*}{ Model } & \multirow[b]{2}{*}{$\mathbf{R}$} & \multirow[b]{2}{*}{$\mathbf{R}^{\mathbf{2}}$} & \multirow[b]{2}{*}{$\begin{array}{c}\text { Modified } \\
\mathbf{R}^{\mathbf{2}}\end{array}$} & \multirow{2}{*}{$\begin{array}{c}\text { Standard } \\
\text { error of } \\
\text { estimated } \\
\text { value }\end{array}$} & \multicolumn{5}{|c|}{ Statistics Variation } & \multicolumn{2}{|c|}{ communist statistics } \\
\hline & & & & & $\begin{array}{c}\mathbf{R}^{2} \\
\text { change } \\
\text { amount }\end{array}$ & $\begin{array}{c}\text { F } \\
\text { change } \\
\text { amount }\end{array}$ & df1 & df2 & $\begin{array}{l}\text { significant } \\
\text { probability } \\
\text { F variation }\end{array}$ & allowance & VIF \\
\hline 1 & $.101 a$ & .010 & .010 & .634 & .010 & 33.110 & 1 & 3207 & .000 & 1.000 & 1.000 \\
\hline 2 & $.219 b$ & .048 & .047 & .622 & .038 & 126.539 & 1 & 3206 & .000 & .999 & 1.001 \\
\hline 3 & $.222 c$ & .049 & .048 & .621 & .001 & 4.765 & 1 & 3205 & .029 & .998 & 1.002 \\
\hline
\end{tabular}

a. Predictive value: (Constant), Liquidity Index

b. Predictive value: (Constant), Liquidity Index, Voluntariness in Retirement

c. Predictive value: (Constant), Liquidity Index, Voluntariness in Retirement, Liquidity Index * Voluntariness in Retirement

d. . Dependent variable : Life Satisfaction after Retirement

Table 7: Verification on Moderator Variable toward Investment Propensity Index and Retired Life Satisfaction

\begin{tabular}{|c|c|c|c|c|c|c|c|c|c|c|c|}
\hline \multirow[b]{2}{*}{ Model } & \multirow[b]{2}{*}{$\mathbf{R}$} & \multirow[b]{2}{*}{$\mathbf{R}^{2}$} & \multirow[b]{2}{*}{$\begin{array}{l}\text { Modified } \\
\mathbf{R}^{2}\end{array}$} & \multirow{2}{*}{$\begin{array}{l}\text { Standard } \\
\text { error of } \\
\text { estimated } \\
\text { value }\end{array}$} & \multicolumn{5}{|c|}{ Statistics Variation } & \multicolumn{2}{|c|}{ communist statistics } \\
\hline & & & & & $\begin{array}{l}\mathbf{R}^{2} \\
\text { change } \\
\text { amount }\end{array}$ & $\begin{array}{l}\text { F } \\
\text { change } \\
\text { amount }\end{array}$ & df1 & df2 & $\begin{array}{l}\text { significant } \\
\text { probability } \\
\text { F variation }\end{array}$ & allowance & VIF \\
\hline 1 & $.020 a$ & .028 & .028 & .636 & .028 & 1.329 & 1 & 3298 & .049 & 1.000 & 1.000 \\
\hline 2 & $.202 b$ & .040 & .040 & .623 & .012 & 138.882 & 1 & 3297 & .000 & .995 & 1.005 \\
\hline 3 & $.204 c$ & .042 & .042 & .623 & .002 & 2.174 & 1 & 3296 & .040 & .999 & 1.001 \\
\hline
\end{tabular}

a. Predictive value: (Constant), Investment Propensity Index

b. Predictive value: (Constant), Investment Propensity Index, Voluntariness in Retirement

c. Predictive value: (Constant), Investment Propensity Index, Voluntariness in Retirement, Investment Propensity Index *

Voluntariness in Retirement

d. Dependent variable : Life Satisfaction after Retirement 
effect in the voluntariness in retirement for the influencing relationship of retired life satisfaction among the retirement satisfaction.

As shown in Table 8, $\mathrm{R}^{2}$ showed gradual increase in Model 1 to $1.5 \%$, Model 2 to $5.2 \%$, and Model 3 to $5.7 \%$ and the variation in F-value was less than 0.000 . This explains that saving propensity index among the sub-variable of economic preparation for later life and has a moderating effect in the voluntariness in retirement for the influencing relationship of retired life satisfaction among the retirement satisfaction.

As shown in Table 9, $\mathrm{R}^{2}$ showed gradual increase in Model 1 to $1.7 \%$, Model 2 to $4.4 \%$, and Model 3 to $4.8 \%$ and the variation in F-value was less than 0.000 . This explains that liquidity index among the sub-variable of economic preparation for later life and has a moderating effect in the voluntariness in retirement for the influencing relationship of retired life satisfaction among the retirement satisfaction.

As shown in Table 10, $\mathrm{R}^{2}$ showed gradual increase in Model 1 to $1.0 \%$, Model 2 to $4.6 \%$, and Model 3 to $4.8 \%$ and the variation in F-value was less than 0.05 . This explains that investment propensity index among the sub-variable of economic preparation for later life and has a moderating effect in the voluntariness in retirement for the influencing relationship of retired life satisfaction among the retirement satisfaction.

\section{Conclusion and Implication}

\subsection{Conclusion Summary}

In the research on how economic preparation for later life influence life after retirement, investment propensity index and liquidity index had a positive influence.

According to life-cycle income hypothesis, savings are the resource for later life formed by adjusting the consumption during the period of high income in preparation for the old age. When a person has a high savings propensity index, it means that the person is well prepared for the retired life.

Table 8: Verification on Moderator Variable toward Saving Propensity Index and Retired Life Satisfaction

\begin{tabular}{|c|c|c|c|c|c|c|c|c|c|c|c|}
\hline \multirow[b]{2}{*}{ Model } & \multirow[b]{2}{*}{$\mathbf{R}$} & \multirow[b]{2}{*}{$\mathbf{R}^{2}$} & \multirow[b]{2}{*}{$\begin{array}{c}\text { Modified } \\
\mathbf{R}^{\mathbf{2}}\end{array}$} & \multirow{2}{*}{$\begin{array}{l}\text { Standard } \\
\text { error of } \\
\text { estimated } \\
\text { value }\end{array}$} & \multicolumn{5}{|c|}{ Statistics Variation } & \multicolumn{2}{|c|}{ communist statistics } \\
\hline & & & & & $\begin{array}{c}\mathbf{R}^{2} \\
\text { change } \\
\text { amount }\end{array}$ & $\begin{array}{c}F \\
\text { change } \\
\text { amount }\end{array}$ & df1 & df2 & $\begin{array}{l}\text { significant } \\
\text { probability } \\
\text { F variation }\end{array}$ & allowance & VIF \\
\hline 1 & $.124 a$ & .015 & .015 & .696 & .015 & 51.601 & 1 & 3290 & .000 & 1.000 & 1.000 \\
\hline 2 & $.227 \mathrm{~b}$ & .052 & .051 & .684 & .036 & 125.368 & 1 & 3289 & .000 & .997 & 1.003 \\
\hline 3 & $.239 c$ & .057 & .056 & .682 & .005 & 18.517 & 1 & 3288 & .000 & .735 & 1.361 \\
\hline
\end{tabular}

a. Predictive value: (Constant), Saving Propensity Index

b. Predictive value: (Constant), Saving Propensity Index, Voluntariness in Retirement

c. Predictive value: (Constant), Saving Propensity Index, Voluntariness in Retirement,

Saving Propensity Index * Voluntariness in Retirement

d. Dependent variable : Satisfaction on Relationship after Retirement

Table 9: Verification on Moderator Variable toward Liquidity Index and Retired Life Satisfaction

\begin{tabular}{|c|c|c|c|c|c|c|c|c|c|c|c|}
\hline \multirow[b]{2}{*}{ Model } & \multirow[b]{2}{*}{$\mathbf{R}$} & \multirow[b]{2}{*}{$\mathbf{R}^{2}$} & \multirow{2}{*}{$\begin{array}{c}\text { Modified } \\
\mathbf{R}^{\mathbf{2}}\end{array}$} & \multirow{2}{*}{$\begin{array}{c}\text { Standard } \\
\text { error of } \\
\text { estimated } \\
\text { value }\end{array}$} & \multicolumn{5}{|c|}{ Statistics Variation } & \multicolumn{2}{|c|}{$\begin{array}{l}\text { communist } \\
\text { statistics }\end{array}$} \\
\hline & & & & & $\begin{array}{c}R^{2} \\
\text { change } \\
\text { amount }\end{array}$ & $\begin{array}{c}F \\
\text { change } \\
\text { amount }\end{array}$ & df1 & df2 & $\begin{array}{l}\text { significant } \\
\text { probability } \\
\text { F variation }\end{array}$ & allowance & VIF \\
\hline 1 & $.085 a$ & .017 & .017 & .701 & .017 & 23.379 & 1 & 3207 & .000 & 1.000 & 1.000 \\
\hline 2 & $.209 b$ & .044 & .043 & .688 & .027 & 122.504 & 1 & 3206 & .000 & .999 & 1.001 \\
\hline 3 & $.220 c$ & .048 & .047 & .686 & .004 & 15.023 & 1 & 3205 & .000 & .998 & 1.002 \\
\hline
\end{tabular}

a. Predictive value: (Constant), Liquidity Index

b. Predictive value: (Constant), Liquidity Index, Voluntariness in Retirement

c. Predictive value: (Constant), Liquidity Index, Voluntariness in Retirement, Liquidity Index * Voluntariness in Retirement

d. Dependent variable : Satisfaction on Relationship after Retirement 
Table 10: Verification on Moderator Variable toward Investment Propensity Index and Retired Life Satisfaction

\begin{tabular}{|c|c|c|c|c|c|c|c|c|c|c|c|}
\hline \multirow[b]{2}{*}{ Model } & \multirow[b]{2}{*}{$\mathbf{R}$} & \multirow[b]{2}{*}{$\mathbf{R}^{2}$} & \multirow{2}{*}{$\begin{array}{c}\text { Modified } \\
\mathbf{R}^{2}\end{array}$} & \multirow{2}{*}{$\begin{array}{l}\text { Standard } \\
\text { error of } \\
\text { estimated } \\
\text { value }\end{array}$} & \multicolumn{5}{|c|}{ Statistics Variation } & \multicolumn{2}{|c|}{$\begin{array}{l}\text { communist } \\
\text { statistics }\end{array}$} \\
\hline & & & & & $\begin{array}{c}\mathbf{R}^{2} \\
\text { change } \\
\text { amount }\end{array}$ & $\begin{array}{c}F \\
\text { change } \\
\text { amount }\end{array}$ & df1 & df2 & $\begin{array}{l}\text { significant } \\
\text { probability } \\
\text { F variation }\end{array}$ & allowance & VIF \\
\hline 1 & $.101 a$ & .010 & .010 & .698 & .010 & 34.038 & 1 & 3298 & .000 & 1.000 & 1.000 \\
\hline 2 & $.215 b$ & .046 & .046 & .685 & .036 & 124.835 & 1 & 3297 & .000 & .995 & 1.005 \\
\hline 3 & $.215 c$ & .048 & .049 & .695 & .045 & 124.835 & 1 & 3296 & .041 & .994 & 1.006 \\
\hline
\end{tabular}

a. Predictive value: (Constant), Investment Propensity Index

b. Predictive value: (Constant), Investment Propensity Index, Voluntariness in Retirement

c. Predictive value: (Constant), Investment Propensity Index, Voluntariness in Retirement, Investment Propensity Index * Voluntariness in Retirement

d. Dependent variable : Satisfaction on Relationship after Retirement

Also, in the research on how later life preparation influence on retired life, savings propensity index and liquidity index had a moderating effect in the voluntariness in retirement.

Savings propensity index and liquidity index are the future-oriented assets necessary for long-term growth and soundness of the household. When a retiree holds high a liquidity index such as financial assets or bank assets, the retiree shows positive psychological changes. As mentioned in the preceding researches, the elderly are living longer and current assets are becoming more important. Like the theory, people think preparation for the future is important.

However, investment propensity had no influence on the retired life and this is because of the components of investment propensity index.

In case of Korea, investment propensity index is usually made in the form of real-estate property. However, the risk relatively increases as the liquidity decreases for excessively high proportion of real-estate property assets. While realestate property assets are important assets formed by the household, residential space's liquidity decreases in Korea. In the future, it is necessary to measure the burden on investment for real-estate property assets like housing expenditure index.

In the research on influence of later life preparation on retired life, the later life preparation had a partial moderating effect for voluntariness in retirement. Meanwhile, it had no influence on psychological changes in life satisfaction after retirement.

Based on above results, this study suggests policies as follows.

The research results commonly showed that variables related to retirement preparation influence on the quality of life and life satisfaction for retired elderly. Also, retired elderly who prepared in advance and retired elderly who have not prepared showed significant differences in life satisfaction.

The problem is that elderly in Korea are facing retirement without enough consideration and preparation in advance, and there are only few social infrastructures for supporting them. Thus, while most elderly in Korea are leaving their work without preparation or plan for retirement, their life satisfaction is greatly threatened due to lack of public later life security system.

\subsection{Discussions and Proposals}

This study examined the influence of socio-demographic characteristics and later life preparation in each field to suggest implications for enhancing life satisfaction and supporting later life preparation through policies. The implications of this study are as follows.

First, institutional supports should be provided for economic preparation for later life even after retirement. This study figured out that the economic preparation for later life holds the biggest influence among the fields of later life preparation influencing on the retirement satisfaction. According to the research, there is a high proportion of elderly receiving the private transfer income among type of later life preparation. This shows that a lot of retirees are highly dependent on their children. Thus, it is necessary to supplement and strengthen public later life security system such as national pension and basic oldage pension for supporting the living expenses of retired elderly.

Second, it is necessary to expand education and retirement plan program based on individual characteristics to help retired elderly to prepare later life in two ways. 
Third, the government and companies should make efforts to refrain from notifying involuntary retirement such as early retirement before retirement age.

This study confirms that the voluntary retirement has a positive influence on the life satisfaction. This result corresponds to the results of preceding researches about relationship between voluntary retirement and retired life. When a person retires voluntarily, one may prepare financially in advance for retirement. In case of involuntary retirement, however, one may experience sense of loss in role and financial difficulties due to unexpected retirement. Thus, voluntariness in retirement influences the general satisfaction over life including the financial aspects of the retired elderly. Especially, early retirement in the main workplace leads to unstable later life. Thus, there should be agreements in the national and business level with social responsibility for helping the employees to retire in the predictable retirement time and prepare for later life in each aspect or decide the path after retirement.

\section{References}

Berkowitz, R., \& Benbenishty, R. (2012). Perceptions of teachers' support, safety, and absence from school because of fear among victims, bullies, and bully-victims. American Journal of Orthopsychiatry, 82(1), 67-74.

Berry, J. W., Kim, U., Minde, T., \& Mok, D. (1988). Comparative studies of acculturative stress. International Immigration Review, 21, 491-511.

Cho, J., \& Kim, S. (2005). On using Mandatory Retirement to Reduce Workforce in Korea. International Economic Journal, 19(2), 283-03.
Choi, K., \& Lee, S. (2007). The Effect of the National Pension System on the Retirement Behavior of the Older Workers in Korea. Korean Social Security Studies, 23(4), 83-103.

Coe, N. B., von Gaudecker H. M., Lindeboom, M., \& Maurer, J. (2012). The Effect of Retirement on Cognitive Functioning. Health Economics, 21(8), 913-27.

Denier, N., Clouston, S. A., Richards, M., \& Hofer, S. M. (2017). Retirement and Cognition: A Life Course View. Advances in Life Course Research, 31, 11-1.

Kontis, V., Bennett, J. E., Mathers, C. D., Li, G., Foreman, K., \& Ezzati, M. (2017). Future Life Expectancy in 35 Industrialised Countries: Projections with a Bayesian Model Ensemble. The Lancet, 389(10076), 1323-1335.

Kim, B., \& Choi, E. (2017). Effects of Retirement on Health and Life Satisfaction. Quarterly Journal of Labor Policy, 17(1), 85-107.

Lee, C., \& Lee, E. (2015). Retirement of Older Wage Workers in Korea: Hazard Model Analysis by Firm Size. Korean Journal of Labour Economics, 38(3), 31-65.

Mazzonna, F., \& Peracchi, F. (2012). Ageing, Cognitive Abilities and Retirement. European Economic Review, 56(4), 691-710.

Roach. (1981). The marital satisfaction scale: Development of measures for intervention research. Journal of Marriage and Family, 43, 537-546.

Rohwedder, S., \& Willis, R. J. (2010). Mental Retirement. The Journal of Economic Perspectives, 24(1), 119-138.

Spreitzer, G. M. (1995). Psychological empowerment in the workplace: Dimensions, measurement and validation. Academy of Management Journal, 38(5), 1442-1485. 